\title{
Hybrid carboxymethyl kappa-carrageenan/carboxymethyl cellulose- based biopolymer electrolytes for dye-sensitized solar cell application
}

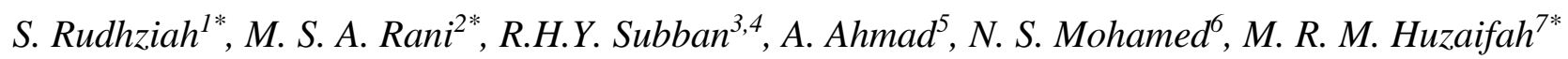 \\ ${ }^{1}$ Centre of Foundation Studies, Universiti Teknologi MARA, Cawangan Selangor, Kampus Dengkil \\ 43800 Dengkil, Selangor, Malaysia. \\ ${ }^{2}$ School of Materials and Mineral Resources Engineering, Universiti Sains Malaysia, 14300 Nibong \\ Tebal, Pulau Pinang, Malaysia \\ ${ }^{3}$ Fakulti Sains Gunaan, Universiti Teknologi MARA, 40450 Shah Alam, Selangor, \\ Malaysia. \\ ${ }^{4}$ Institut Sains, Universiti Teknologi MARA, 40450 Shah Alam, Selangor, Malaysia. \\ ${ }^{5}$ School of Chemical Science and Food Technology, Universiti Kebangsaan Malaysia, 43600 Bangi, \\ Malaysia. \\ ${ }^{6}$ Centre for Foundation Studies in Science, University of Malaya, 50603 Kuala Lumpur, Malaysia \\ ${ }^{7}$ Department of Crop Science, Faculty of Agricultural Science and Forestry, Universiti Putra Malaysia \\ Bintulu Campus, 97000 Bintulu, Sarawak. \\ *E-mail: rudhziah@uitm.edu.my ; iker.asmal55@gmail.com ; muhammadhuzaifah@upm.edu.my
}

Received: 23 March 2021 / Accepted: 29 August 2021 / Published: 6 December 2021

\begin{abstract}
Natural biopolymers have recently attracted a lot of attention for the development of new polymer electrolytes due to their environmental friendliness, nontoxicity, and abundance in nature. Biopolymer electrolytes based on carboxymethyl kappa-carrageenan/carboxymethyl cellulose incorporated with sodium iodide were prepared and their structural and electrochemical stability were investigated using electrochemical impedance spectroscopy, Fourier transform infrared spectroscopy, transference number measurement, and linear sweep voltammetry. The film containing $30 \mathrm{wt} \%$ sodium iodide had the highest ionic conductivity and the highest relative number of charge carriers at room temperature. The relative number of charge carriers for each prepared electrolyte film in this study increased with salt concentration, according to Barker's electrolyte dissociation theory. The highest conducting electrolyte and the lowest salt concentration electrolyte films were used to fabricate and characterise dye-sensitized solar cell (DSSC). These DSSCs responded well to a light intensity of $100 \mathrm{~mW} \mathrm{~cm}^{-2}$.
\end{abstract}

Keywords: Polymer blend; electrolytes; carboxymethyl kappa-carrageenan; carboxymethyl cellulose; sodium iodide.

\section{FULL TEXT}


(C) 2022 The Authors. Published by ESG (www.electrochemsci.org). This article is an open access article distributed under the terms and conditions of the Creative Commons Attribution license (http://creativecommons.org/licenses/by/4.0/). 